\title{
Comparative Evaluation of Agroindustrial Byproducts for the Production of Alkaline Protease by Wild and Mutant Strains of Bacillus subtilis in Submerged and Solid State Fermentation
}

\author{
Hamid Mukhtar and Ikramul Haq \\ Institute of Industrial Biotechnology, GC University, Lahore 54000, Pakistan \\ Correspondence should be addressed to Hamid Mukhtar; hamidwaseer@yahoo.com
}

Received 21 August 2013; Accepted 15 September 2013

Academic Editors: P. Poltronieri and S. Sreenivasaprasad

Copyright (C) 2013 H. Mukhtar and I. Haq. This is an open access article distributed under the Creative Commons Attribution License, which permits unrestricted use, distribution, and reproduction in any medium, provided the original work is properly cited.

\begin{abstract}
The present study describes the screening of different agroindustrial byproducts for enhanced production of alkaline protease by a wild and EMS induced mutant strain of Bacillus subtilis $\mathrm{IH}-72^{\text {EMS8 }}$. During submerged fermentation, different agro-industrial byproducts were tested which include defatted seed meals of rape, guar, sunflower, gluten, cotton, soybean, and gram. In addition to these meals, rice bran, wheat bran, and wheat flour were also evaluated for protease production. Of all the byproducts tested, soybean meal at a concentration of $20 \mathrm{~g} / \mathrm{L}$ gave maximum production of the enzyme, that is, $5.74 \pm 0.26 \mathrm{U} / \mathrm{mL}$ from wild and $11.28 \pm 0.45 \mathrm{U} / \mathrm{mL}$ from mutant strain, during submerged fermentation. Different mesh sizes (coarse, medium, and fine) of the soybean meal were also evaluated, and a finely ground soybean meal (fine mesh) was found to be the best. In addition to the defatted seed meals, their alkali extracts were also tested for the production of alkaline protease by Bacillus subtilis, but these were proved nonsignificant for enhanced production of the enzyme. The production of the enzyme was also studied in solid state fermentation, and different agro-industrial byproducts were also evaluated for enzyme production. Wheat bran partially replaced with guar meal was found as the best substrate for maximum enzyme production under solid state fermentation conditions.
\end{abstract}

\section{Introduction}

Microorganisms represent an excellent source of proteolytic enzymes owing to their broad biochemical diversity and their suitability to genetic manipulation. Microbial proteases account for approximately $40 \%$ of the total worldwide enzyme sales [1]. Proteases from microbial sources are preferred to the enzymes from plant and animal sources, since they possess almost all the characteristics desired for their biotechnological applications. In addition, the microbial enzymes are not subjected to any of the production and supply limitations.

Alkaline proteases are produced by a large number of bacterial species; however, Bacillus species possess remarkable biotechnological value due to their nonpathogenicity of various species and the ability to produce extracellular protease in large amounts. Different species of Bacillus producing high titers of protease include B. subtilis and B. licheniformis $[2,3]$, B. pseudofirmus [4], B. cereus, B. pumilus [5], B. stearothermophilus [6], B. intermedius [7], B. amyloliquefaciens [8], and Bacillus mycoides [9]. Protease production has also been reported by alkalophilic Streptomyces spp. [10], Pseudomonas spp. [11], Photorhabdus spp. [12], Lactobacillus spp. [13], Alcaligenes faecalis [14], and Xanthomonas maltophilia [15].

Proteases can be obtained economically and profitably from microorganisms by the process of fermentation using submerged as well as solid state fermentation. Many of the organisms excrete more than one kind of protease, and the type of proteolytic enzyme formed may depend upon the composition of the medium [16]. The agroindustrial byproducts when used in the submerged culture medium are excellent and cheap sources of proteins, carbohydrates, and minerals needed for the growth of microorganisms and 
synthesis of microbial enzymes. Solid state fermentation (SSF) has the potential to serve as a production method for microbial products and processes typically using agricultural crop and processing residues. Such substrates are structurally and mutationally complex, often creating a supportive environment compared to the submerged cultivation method.

Pakistan is an agricultural country so it has wide variety of agroindustrial byproducts which are cheaply available in the market. These agroindustrial by-products, being a good source of proteins, carbohydrates, and minerals, can be exploited for the biosynthesis of industrial enzymes through microorganisms. These substrates include agricultural crop and processing residues such as wheat bran, soybean meal, sugar cane bagasse, corn stover, residues of coffee, paper and oil processing, cereal brans and husks, and different defatted oil seed cakes. Bacteria generally synthesize proteolytic enzymes, when grown in protein medium, however, very few bacteria can also produce proteases on protein-free media [16], and these agroindustrial by-products present a wide variety of protein rich substrates.

The present study was undertaken to evaluate the indigenously available cheap agroindustrial resources for the production of alkaline protease from a locally isolated mutant strain of Bacillus subtilis using both the submerged and solid state fermentations.

\section{Materials and Methods}

2.1. Microorganism. The microorganism used in the present study was Bacillus subtilis IH-72 which was originally isolated from the soil of tannery area and identified in our labs. The wild strain has been maintained in the culture bank of the Institute of Industrial Biotechnology, GC University, Lahore.

2.2. Random Mutagenesis. The random mutagenesis of the wild strain of Bacillus subtilis was carried out using ethyl methane sulfonate (EMS) for enhanced production of proteases according to the protocols developed in our labs. The wild culture was subcultured in nutrient broth medium overnight until a density of $3-5 \times 10^{8} \mathrm{CFU} / \mathrm{mL}$ was reached. The culture was then centrifuged at $6000 \mathrm{rpm}$ for $10 \mathrm{~min}$. The pellet was washed with sterilized saline water and resuspended in half the original volume of nutrient broth containing $0.2 \mathrm{M}$ Tris ( $\mathrm{pH}$ 7.5). EMS was then added to the bacterial suspension to the final concentration of $15 \mathrm{ul} / \mathrm{mL}$ and mixed vigorously. Then the tubes were incubated in shaking water bath at $37^{\circ} \mathrm{C}$ for 30-180 $\mathrm{min}$. After incubation, the culture was centrifuged and washed with sterilized saline water. The pellet was resuspended in $10 \mathrm{~mL}$ of nutrient broth and allowed to grow overnight. The saturated culture was diluted up to $10^{6}$ and plated on peptone-yeast extract-casein agar plates. The plates were incubated at $37^{\circ} \mathrm{C}$ for $24-48 \mathrm{hrs}$ for growth of the mutagenized cells. The bacterial colonies showing bigger zones of casein hydrolysis as compared to wild strain were picked up and transferred to the nutrient broth slants. All the isolated mutants were screened for enhancement in the enzyme production (data not shown) and the best mutant strain namely Bacillus subtilis IH-72 ${ }^{\text {EMS8 }}$ was selected for further studies.
2.3. Fermentation Experiments. The fermentation experiments for the production of extracellular alkaline protease by Bacillus subtilis IH-72 were carried out in flasks as solid state and submerged fermentation and laboratory scale stirred fermenter.

2.4. Inoculum Preparation. Fifty milliliter of preculture medium consisting of $0.8 \%$ nutrient broth (peptone, $0.3 \%$; yeast extract, $0.4 \% ; \mathrm{pH} 7$ ) was transferred to the cotton-plugged $250 \mathrm{~mL}$ Erlenmeyer flask and sterilized in an autoclave for $15 \mathrm{~min}$ at $15 \mathrm{Lb} /$ inch $^{2}\left(121^{\circ} \mathrm{C}\right)$. After cooling at room temperature, the flask was inoculated aseptically with a loopful of bacteria from $48 \mathrm{hrs}$ old slant. The flask was then placed in the rotary shaking incubator at $37^{\circ} \mathrm{C}$ for $24 \mathrm{hrs}$. The bacterial growth was used as an inoculum in both the submerged and solid state fermentations.

2.5. Submerged Fermentation. Fifty milliliter of the fermentation medium composed of $(\mathrm{g} / \mathrm{L})$ soybean meal, 10; glucose, 10; polypeptone, $10 ; \mathrm{KH}_{2} \mathrm{PO}_{4}, 1.0$; and $\mathrm{Na}_{2} \mathrm{CO}_{3}, 5.0$ ( $\mathrm{pH} 8.5$ ) contained in $250 \mathrm{~mL}$ cotton-plugged Erlenmeyer flask was sterilized in an autoclave for $15 \mathrm{~min}$ at $15 \mathrm{lb} / \mathrm{inch}^{2}\left(121^{\circ} \mathrm{C}\right)$ and cooled at room temperature. Each flask was then inoculated with $1 \mathrm{~mL}$ of vegetative inoculum of bacterial cells containing $5.2-5.3 \times 10^{8} \times \mathrm{CFU} / \mathrm{mL}$. The flasks were then placed in the rotary shaking incubator $(200 \mathrm{rpm})$ at $35^{\circ} \mathrm{C}$ for $48 \mathrm{hrs}$. After a fixed incubation period, the fermented broth was centrifuged at $5000 \mathrm{rpm}$ for $10 \mathrm{~min}$. The supernatant was analyzed for protease assay and estimation of dry cell mass.

2.6. Solid State Fermentation. For solid state fermentation, $5 \mathrm{~g}$ of wheat bran and $5 \mathrm{~g}$ of soybean meal contained in $250 \mathrm{~mL}$ Erlenmeyer flask were moistened with $10 \mathrm{~mL}$ of distilled water. The flasks were cotton-plugged and sterilized in an autoclave. After sterilization, the medium was cooled at room temperature and was inoculated with $1.0 \mathrm{~mL}$ of the bacterial inoculum as prepared earlier. The flasks were vigorously shaken to distribute the inoculum uniformly in the medium and were incubated statically at $37^{\circ} \mathrm{C}$ for $48 \mathrm{hrs}$. During incubation, the flasks were shaken twice a day for achieving homogeneity.

The fermetation batches were run in triplicate, and the mean of three was reported in the results. During all the experiments, calibrated glassware and analytical grade chemicals were used.

\section{Analytical Methods}

3.1. Assay of Protease. The method of McDonald and Chen [17] was used for the assay of protease. Casein (1\% solution in $0.1 \mathrm{M}$ phosphate buffer of $\mathrm{pH} 8.0$ ) was incubated with the enzyme sample at $30^{\circ} \mathrm{C}$ for $30 \mathrm{~min}$. The reaction was arrested by the addition of $5 \mathrm{~mL}$ of $5 \%$ trichloroacetic acid (TCA) solution. The mixture was centrifuged at $5000 \mathrm{rpm}$ for $10 \mathrm{~min}$, and $1 \mathrm{~mL}$ of supernatant was mixed with $5 \mathrm{~mL}$ of alkaline regent. To this mixture $1 \mathrm{~mL}$ of $1 \mathrm{~N} \mathrm{NaOH}$ was added to make the contents of the tube alkaline. After $10 \mathrm{~min}$., $0.5 \mathrm{~mL}$ of Folin and Ciocalteau reagent was added to the test tubes and 


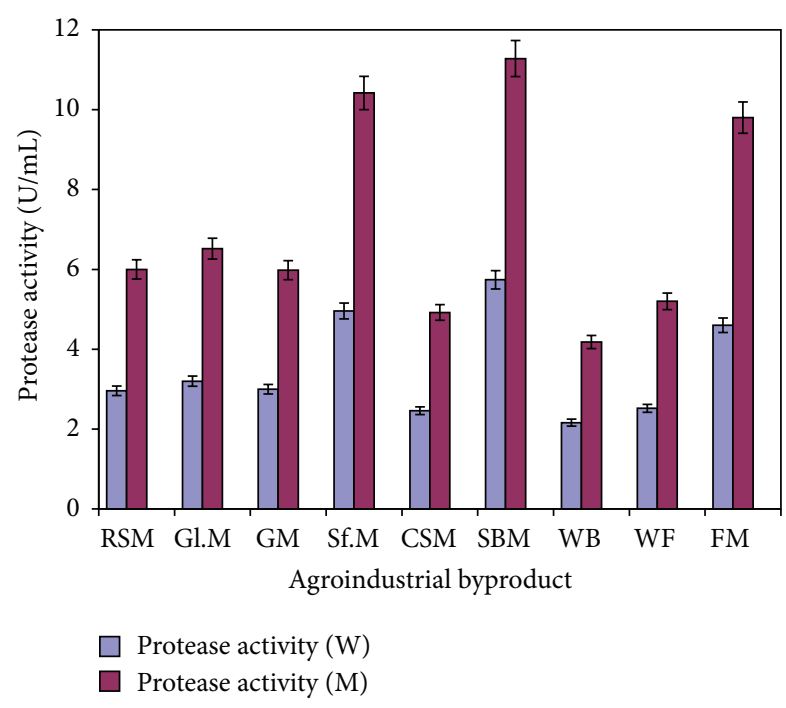

FIGURE 1: Screening of different agroindustrial byproducts for the production of alkaline protease by Bacillus subtilis IH-72 and its mutant derivative in shake flasks. (Initial $\mathrm{pH} 8.5$; incubation temperature $37^{\circ} \mathrm{C}$; fermentation period (W = wild) $48 \mathrm{hrs}$; fermentation period ( $\mathrm{M}=$ mutant) $42 \mathrm{hrs}$; fermentation medium M4. Each value is an average of three parallel replicates. Y bars indicate the standard error of mean value.) RSM: rape seed meal; Gl.M: gluten meal; GM: guar meal; Sf.M: sunflower meal; CSM: cotton seed meal; SBM: soybean meal; WB: wheat bran; WF: wheat flour; FM: fish meal.

mixed. The blue colour produced was measured with UV-VIS spectrophotometer at $700 \mathrm{~nm}$ after $30 \mathrm{~min}$.

One unit of protease activity is defined as the amount of enzyme required to produce and increase 0.1 in optical density at $700 \mathrm{~nm}$ under the defined conditions.

Abbreviations used: RSM: rape seed meal; Gl.M: gluten meal; GM: guar meal; Sf.M: sunflower meal; CSM: cotton seed meal; SBM: soybean meal; WB: wheat bran; WF: wheat flour; FM: fish meal.

\section{Results}

4.1. Screening of Agroindustrial Substrates during Submerged Fermentation. Figure 1 depicts the screening of different agroindustrial byproducts for the production of alkaline protease by wild and mutant strains of Bacillus subtilis in submerged fermentation. Of all the agroindustrial byproducts evaluated, soybean meal was found to be the best substrate for production of alkaline protease showing a yield of $5.74 \pm$ $0.26 \mathrm{U} / \mathrm{mL}$ (wild) and $11.28 \pm 0.45 \mathrm{U} / \mathrm{mL}$ (mutant). The other substrates such as rape seed meal, gluten meal, guar meal, sunflower meal, cotton seed meal, wheat bran, wheat flour, and fish meal gave $2.96 \pm 0.12,3.2 \pm 0.13,3.0 \pm 0.12,4.9 \pm 0.196$, $6.0 \pm 0.24,2.46 \pm 0.098,2.16 \pm 0.86$, and $2.52 \pm 0.10 \mathrm{U} / \mathrm{mL}$ with wild strain and $6.0 \pm 0.24,6.52 \pm 0.26,5.9 \pm 0.24,8.0 \pm 0.32$, $10.42 \pm 0.42,4.92 \pm 0.196,4.18 \pm 0.167$, and $5.2 \pm 0.21 \mathrm{U} / \mathrm{mL}$ of alkaline protease with mutant strain, respectively. The alkali extracts of abovementioned seed meals were also evaluated for the production of alkaline protease by Bacillus subtilis, but these were proved nonsignificant for enhanced production of the enzyme (data not shown).

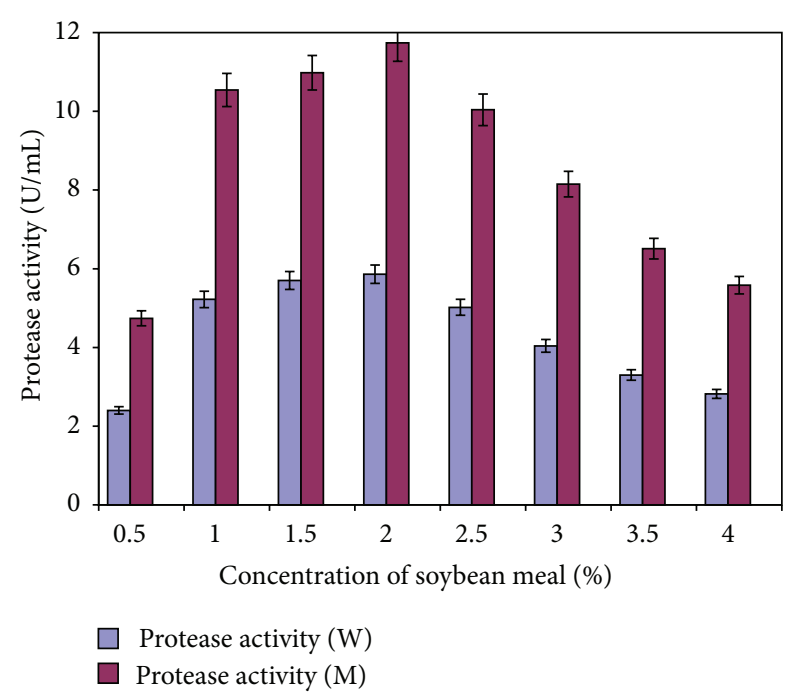

FIGURE 2: Effect of different concentrations of soybean meal on the production of alkaline protease by Bacillus subtilis IH-72 and its mutant derivative in shake flasks. (Initial $\mathrm{pH} 8.5$; incubation temperature $37^{\circ} \mathrm{C}$; fermentation period (W) $48 \mathrm{hrs}$; fermentation period (M) $42 \mathrm{hrs;} \mathrm{fermentation} \mathrm{medium} \mathrm{M4.} \mathrm{Each} \mathrm{value} \mathrm{is} \mathrm{an}$ average of three parallel replicates. Y bars indicate the standard error of mean value.)

In continuation, further experiments were performed to find out the optimum concentration of soybean meal in the fermentation medium for the production of alkaline protease by the wild and mutant organism (Figure 2). The soybean meal was added to the culture medium at different concentrations ranging from 0.5 to $4.0 \%(\mathrm{w} / \mathrm{v})$. The results showed that the soybean meal at a concentration of $2 \%$ was best for maximum biosynthesis of alkaline protease (5.86 \pm $0.23 \mathrm{U} / \mathrm{mi}(\mathrm{W})$ and $11.74 \pm 0.47 \mathrm{U} / \mathrm{mL}(\mathrm{M}))$. Lesser or greater concentration of soybean meal than $2 \%(\mathrm{w} / \mathrm{v})$ resulted in a decreased amount of alkaline protease production by the microorganism.

In another set of experiments, the mesh size of soybean meal was optimized for maximum biosynthesis of alkaline protease by both the wild and mutant strains of Bacillus subtilis IH-72 (Figure 3). Soybean meal in three different mesh sizes $(60,100$, and 150) was added to the culture medium and fermentation was carried out. The results of the experiments as shown in Figure 3 depicted that the finely ground soybean meal ( 60 mesh) supported maximum growth of the microorganism and production of enzyme in case of both the wild $(5.84 \pm 0.25 \mathrm{U} / \mathrm{mL})$ and mutant $(11.82 \pm 0.48)$ so was best for biosynthesis of the enzyme. Therefore, the culture medium was supplemented with soybean meal having a mesh size of 60 at a concentration of $2 \%$ for maximum production of alkaline protease by Bacillus subtilis IH-72 and its mutant derivative.

4.2. Screening of Agroindustrial Substrates during Solid State Fermentation. Selection of a suitable substrate for solid state fermentation is of great importance for a successful fermentation process. Different substrates such as rice polish, linseed meal, rape seed meal, guar meal, cotton gluten meal, 


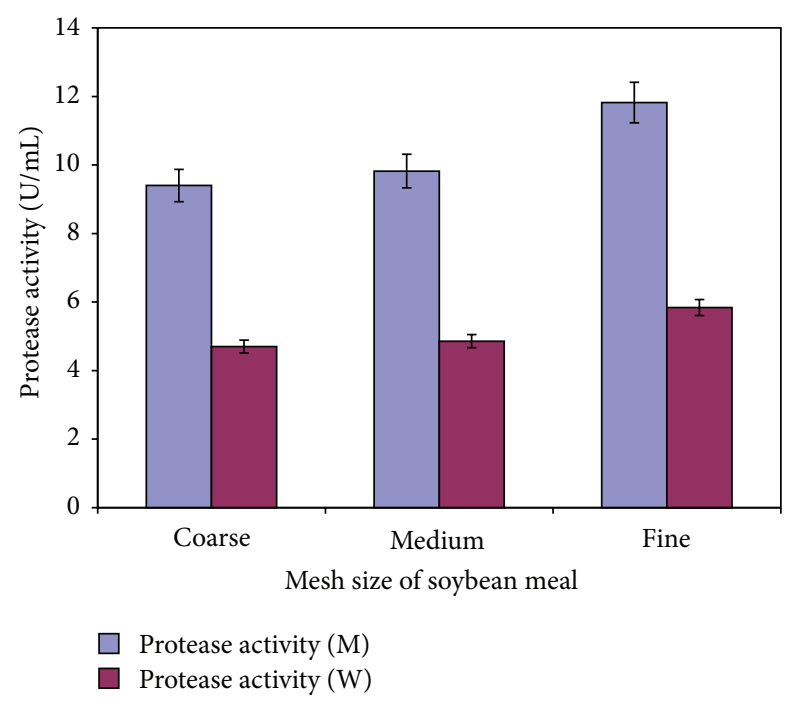

FIGURE 3: Effect of mesh size of soybean meal on the production of alkaline protease by Bacillus subtilis $\mathrm{IH}-72$ and its mutant derivative in shake flasks. (Initial $\mathrm{pH} 8.5$; incubation temperature $37^{\circ} \mathrm{C}$; fermentation period (W) $48 \mathrm{hrs}$; fermentation period (M) $42 \mathrm{hrs}$; fermentation medium M4. Each value is an average of three parallel replicates. Y bars indicate the standard error of mean value.)

sunflower meal, gram husk, soybean meal, wheat bran, and fish meal were evaluated as source of protein, carbohydrate, and minerals for the synthesis of protease by Bacillus subtilis IH-72 under solid state fermentation conditions. Figure 4 shows that out of all the fermentation substrate examined, wheat bran gave maximum enzyme production, that is, $85.03 \mathrm{U} / \mathrm{g}$. It was decreased in the order guar meal $(79.25 \mathrm{U} / \mathrm{g})$ $>$ soybean meal $(53.15 \mathrm{U} / \mathrm{g})>$ gram husk $(40.69 \mathrm{U} / \mathrm{g})>$ linseed meal $(35.28 \mathrm{U} / \mathrm{g})>$ sunflower meal $(32.45 \mathrm{U} / \mathrm{g})>$ rape seed meal $(28.20 \mathrm{U} / \mathrm{g})>$ cotton gluten meal $(22.1 \mathrm{U} / \mathrm{g})>$ rice polish $(20.50 \mathrm{U} / \mathrm{g})>$ fish meal $(20.0 \mathrm{U} / \mathrm{g})$.

As the biosynthesis of alkaline protease was found maximum in the presence of wheat bran and guar meal was next to wheat bran in this regard (Figure 4), so wheat bran was partially replaced with guar meal for maximizing the enzyme production. It was found that the alkaline protease formation was maximum $(89.15 \mathrm{U} / \mathrm{g})$ when wheat bran was replaced with guar meal at a ratio of $8: 2$ (Figure 5). Further replacement of wheat bran with guar meal resulted in the decreased production of protease because it reduced the porosity of substrate and resulted in the scum formation.

\section{Discussion}

The selection of an ideal agroindustrial byproduct for enzyme production depends on several factors, which are mainly related to cost and availability of the material and thus may involve screening of several such byproducts. During submerged fermentation, different agroindustrial byproducts were evaluated for the production of alkaline protease by the organism, and soybean meal, which is a byproduct of oil mills, was found to be the best protein substrate for the induction of protease production by Bacillus subtilis IH-72. Soybean

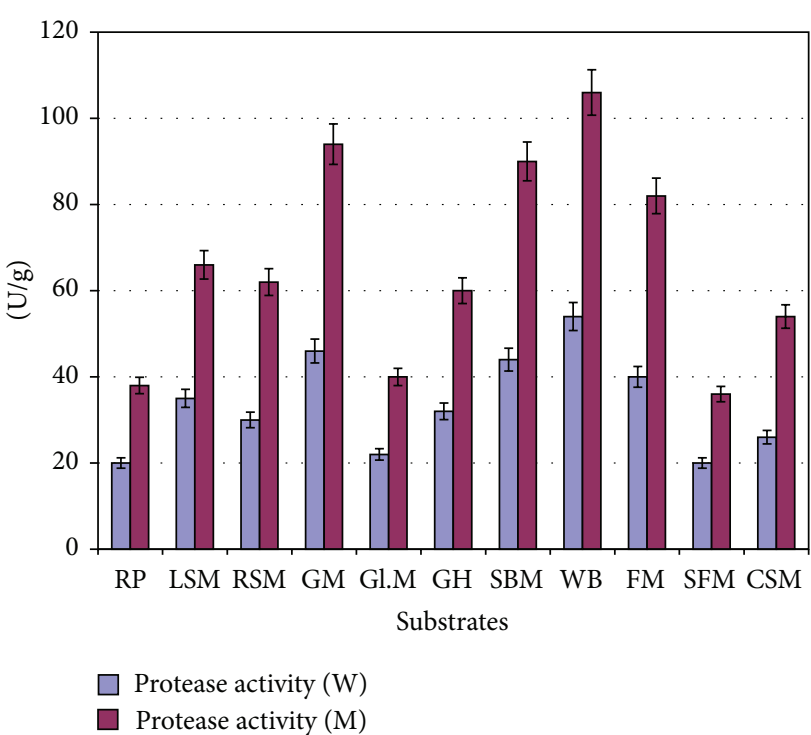

FIGURE 4: Screening of different agroindustrial byproducts for the production of alkaline protease by Bacillus subtilis IH-72 and its mutant derivative using solid state fermentation. (Incubation temperature $=37^{\circ} \mathrm{C}$; incubation period $=48 \mathrm{hrs}$; moisture level $=$ $100 \%$; diluent $=$ distilled water; $\mathrm{pH}$ of diluent 7.0 ; inoculum size $10 \%$.) Each value is a mean of three replicates. Y error bars indicate the standard error from the mean. RP: rice polish; LSM: linseed meal; RSM: rape seed meal; GM: guar meal; Gl.M: gluten meal; GH: gram husk; SBM: soybean meal; WB: wheat bran; FM: fish meal; SFM: sunflower meal; CSM: cotton seed meal.

meal contains ( $\% \mathrm{~s} / \mathrm{s}$ ) protein, 45 ; carbohydrates, 32.2 ; fat, 0.8 ; $\mathrm{Ca}, 0.25 ; \mathrm{Mg}, 0.27 ; \mathrm{P}, 0.6 ; \mathrm{K}, 1.92$; and $\mathrm{S}, 0.32$, in addition to the vitamins and amino acids (Traders Protein, USA). It is evident that soybean meal contains good amount of protein and other nutrients which are supportive of profuse growth and secretion of proteolytic enzyme. Several other workers have also used soybean meal as a substrate in the medium for induction of proteases by Bacillus species [18, 19]. On the other hand, some proteo-chitinous (milled shrimp waste) and nonproteinaceous substrates have also been used to produce protease by Bacillus spp. $[16,20]$.

The reason for the highest yield with wheat bran in case of solid state fermentation was due to the fact that it provided an adequate source of protein, carbohydrates, and minerals needed by the microorganism for growth and biosynthesis of protease. It also had a large surface area per unit volume for a good bacterial growth on the solid/gas interfaces. The superior effect of natural substrates in enzyme production may also be due to the presence of growth promoters in enough amounts covering the requirements of the bacterial growth and enzyme production. Several other workers have also reported wheat bran as the best substrate to yield a higher enzyme production from Bacillus species under solid state fermentation [21, 22]. Bacillus horikoshii, B. subtilis, and B. circulans have been reported to synthesize the maximum alkaline proteases using soybean meal, rice bran, and green gram husk, respectively $[18,23]$.

The increased production of protease with wheat bran in combination with guar meal may be due to the fact that wheat 


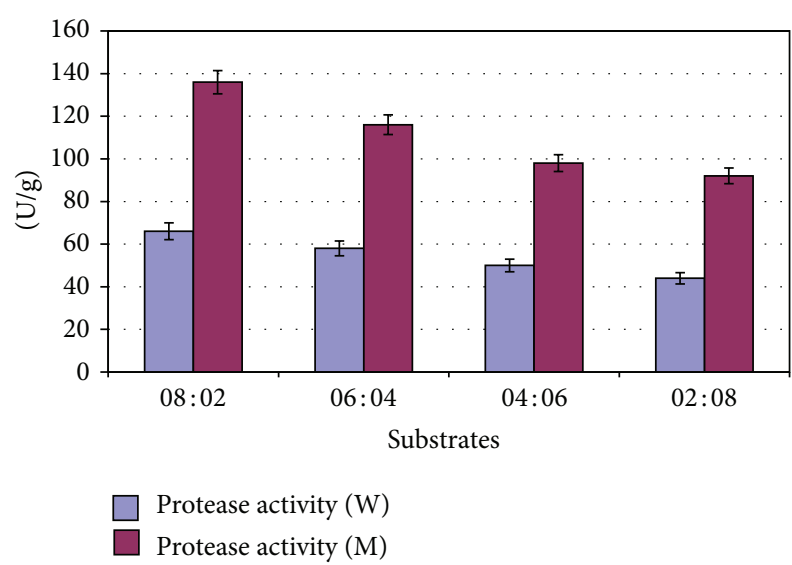

FIGURE 5: Effect of partial replacement of wheat bran with guar meal on the production of alkaline protease by Bacillus subtilis $\mathrm{IH}-$ 72 using solid state fermentation. (Incubation temperature $=37^{\circ} \mathrm{C}$; incubation period $=48 \mathrm{hrs}$; moisture level $=100 \%$; diluent $=$ distilled water; $\mathrm{pH}$ of diluent $=7.0$; inoculum size $=10 \%$.) Each value is a mean of three replicates. Y error bars indicate the standard error from the mean.

bran alone may be deficient in some nutrients and guar meal might have fulfilled the deficient nutritional requirement of the organism for growth. Resulted fermentation substrate became very supportive for microbial growth and yield of alkaline protease by Bacillus subtilis IH-72. It was also reported that Bacillus subtilis gave maximum yield of alkaline protease when wheat bran was partially replaced with soybean meal $(9: 1)$ as compared with other substrates [24].

\section{Conclusion}

The present study concludes that the cheaply available industrial byproducts have a good potential and can be used as substrates for the production of different value-added products such as commercial enzymes from different microorganisms using either submerged or solid state fermentations.

\section{Conflict of Interests}

The authors declare that there is no conflict of interests regarding the publication of this paper.

\section{References}

[1] T. Godfrey, "Leather," in Industrial Enzymology, T. Godfrey and S. West, Eds., pp. 285-291, Stocton Press, New York, NY, USA, 2nd edition, 1996.

[2] V. F. Soares, L. R. Castilho, E. P. S. Bon, and D. M. G. Freire, "High-yield Bacillus subtilis protease production by solid-state fermentation," Applied Biochemistry and Biotechnology A, vol. 121, no. 1-3, pp. 311-319, 2005.

[3] M. Shaheen, A. A. Shah, A. Hameed, and F. Hasan, "Influence of culture conditions on production and activity of protease from Bacillus subtilis BS1," Pakistan Journal of Botany, vol. 40, no. 5, pp. 2161-2169, 2008.
[4] N. R. Pedersen, R. Wimmer, R. Matthiesen, L. H. Pedersen, and A. Gessesse, "Synthesis of sucrose laurate using a new alkaline protease," Tetrahedron Asymmetry, vol. 14, no. 6, pp. 667-673, 2003.

[5] J. M. Kim, W. J. Lim, and H. J. Suh, "Feather-degrading Bacillus species from poultry waste," Process Biochemistry, vol. 37, no. 3, pp. 287-291, 2001.

[6] P. Dürrschmidt, J. Mansfeld, and R. Ulbrich-Hofmann, "Differentiation between conformational and autoproteolytic stability of the neutral protease from Bacillus stearothermophilus containing an engineered disulfide bond," European Journal of Biochemistry, vol. 268, no. 12, pp. 3612-3618, 2001.

[7] N. P. Balaban, M. R. Sharipova, A. M. Usmanova, E. L. Itskovich, and I. B. Leshchinskaia, "Alkaline extracellular proteinase from Bacillus intermedius; Isolation, purification, and some properties of the enzyme," Biokhimiya, vol. 58, no. 12, pp. 1923-1928, 1993.

[8] S. George, V. Raju, M. R. Krishnan, T. V. Subramanian, and K. Jayaraman, "Production of protease by Bacillus amyloliquefaciens in solid-state fermentation and its application in the unhairing of hides and skins," Process Biochemistry, vol. 30, no. 5, pp. 457-462, 1995.

[9] M. A. Abdel-Naby, A.-M. S. Ismail, S. A. Ahmed, and A. F. Abdel Fattah, "Production and immobilization of alkaline protease from Bacillus mycoides," Bioresource Technology, vol. 64, no. 3, pp. 205-210, 1998.

[10] A. Hiramatsu and T. Ouchi, "Zinc of neutral proteinase from Streptomyces naraensis," Agricultural and Biological Chemistry, vol. 42, no. 7, pp. 1309-1313, 1978.

[11] S. Ravaud, P. Gouet, R. Haser, and N. Aghajari, "Probing the role of divalent metal ions in a bacterial psychrophilic metalloprotease: binding studies of an enzyme in the crystalline state by X-ray crystallography," Journal of Bacteriology, vol. 185, no. 14, pp. 4195-4203, 2003.

[12] C. M. Cabral, A. Cherqui, A. Pereira, and N. Simões, "Purification and characterization of two distinct metalloproteases secreted by the entomopathogenic bacterium Photorhabdus sp. strain Az29," Applied and Environmental Microbiology, vol. 70, no. 7, pp. 3831-3838, 2004.

[13] T. Bintsis, A. Vafopoulou-Mastrojiannaki, E. LitopoulouTzanetaki, and R. K. Robinson, "Protease, peptidase and esterase activities by lactobacilli and yeast isolates from Feta cheese brine," Journal of Applied Microbiology, vol. 95, no. 1, pp. 68-77, 2003

[14] E. B. Thangam and G. S. Rajkumar, "Purification and characterization of alkaline protease from Alcaligenes faecalis," Biotechnology and Applied Biochemistry, vol. 35, no. 2, pp. 149$154,2002$.

[15] C. H. De Toni, M. F. Richter, J. R. Chagas, J. A. P. Henriques, and C. Termignoni, "Purification and characterization of an alkaline serine endopeptidase from a feather-degrading Xanthomonas maltophilia strain," Canadian Journal of Microbiology, vol. 48, no. 4, pp. 342-348, 2002.

[16] Presscott and Dunn's, Industrial Microbiology, CBS Publishers \& Distributors, New Delhi, India, 4th edition, 2004.

[17] C. E. McDonald and L. L. Chen, "The Lowry modification of the Folin reagent for determination of proteinase activity," Analytical Biochemistry, vol. 10, no. 1, pp. 175-177, 1965.

[18] H.-S. Joo, C. G. Kumar, G.-C. Park, K. T. Kim, S. R. Paik, and C.S. Chang, "Optimization of the production of an extracellular alkaline protease from Bacillus horikoshii," Process Biochemistry, vol. 38, no. 2, pp. 155-159, 2002. 
[19] S. S. Nilegaonkar, P. P. Kanekar, S. S. Sarnaik, and A. S. Kelkar, "Production, isolation and characterization of extracellular protease of an alkaliphilic strain of Arthrobacter ramosus, MCM B-351 isolated from the alkaline lake of Lonar, India," World Journal of Microbiology and Biotechnology, vol. 18, no. 8, pp. 785789, 2002.

[20] L. I. Rojas-Avelizapa, R. Cruz-Camarillo, M. I. Guerrero, R. Rodríguez-Vázquez, and J. E. Ibarra, "Selection and characterization of a proteo-chitinolytic strain of Bacillus thuringiensis, able to grow in shrimp waste media," World Journal of Microbiology and Biotechnology, vol. 15, no. 2, pp. 261-268, 1999.

[21] F. Uyar and Z. Baysal, "Production and optimization of process parameters for alkaline protease production by a newly isolated Bacillus sp. under solid state fermentation," Process Biochemistry, vol. 39, no. 12, pp. 1893-1898, 2004.

[22] S. Imtiaz, H. Mukhtar, and I. Haq, "Production of alkaline protease by Bacillus subtilis using solid state fermentation," African Journal of Microbiology Research, vol. 7, no. 16, pp. 15581568, 2013.

[23] R. S. Prakasham, C. S. Rao, and P. N. Sarma, "Green gram huskan inexpensive substrate for alkaline protease production by Bacillus sp. in solid-state fermentation," Bioresource Technology, vol. 97, no. 13, pp. 1449-1454, 2006.

[24] H. Haque, B. A. Nadeem, and M. A. Qadeer, "Biosynthesis of enzyme by solid state fermentation; Production of protease by Bacillus subtilis," Science International, vol. 2, no. 1, pp. 31-34, 1990. 

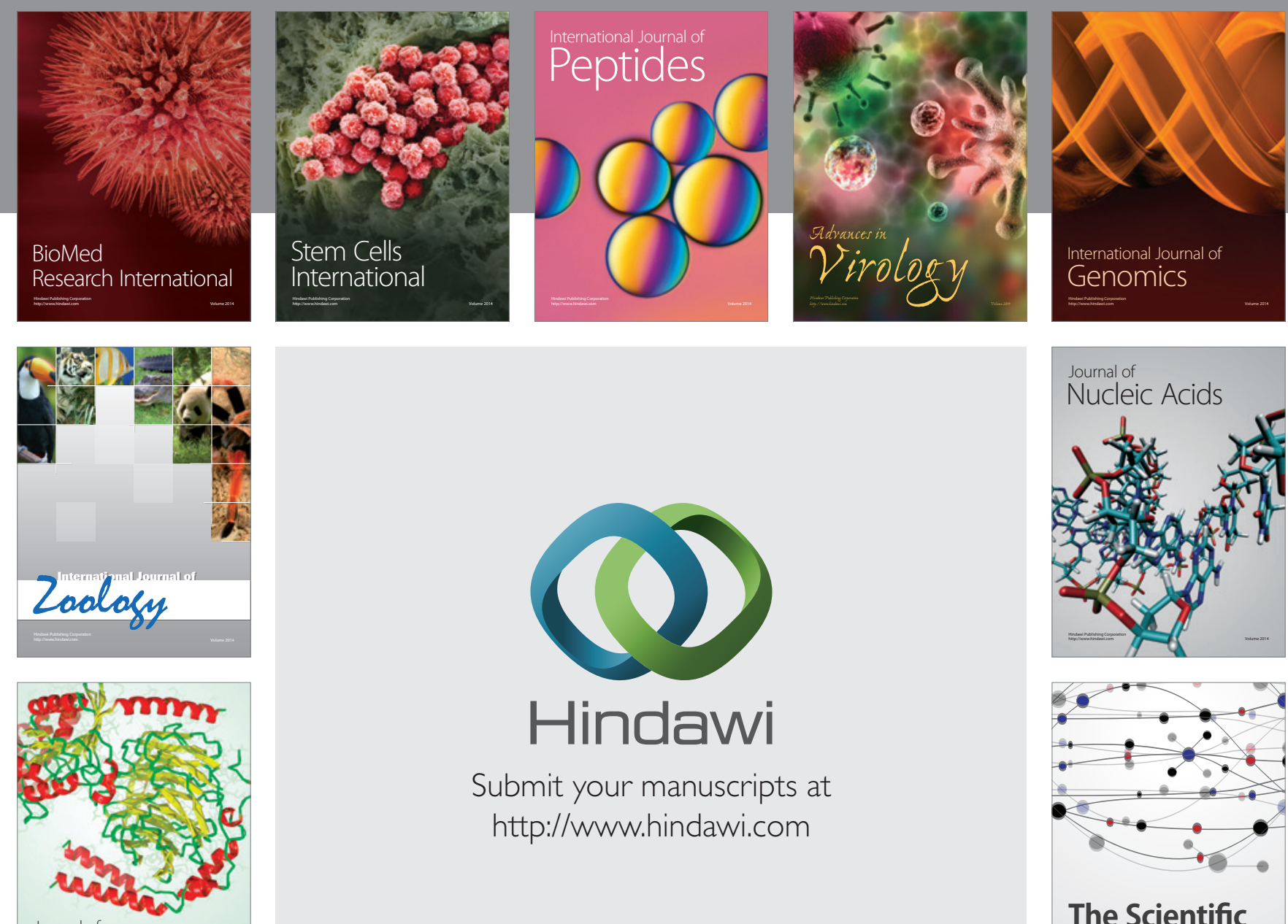

Submit your manuscripts at

http://www.hindawi.com

Journal of
Signal Transduction
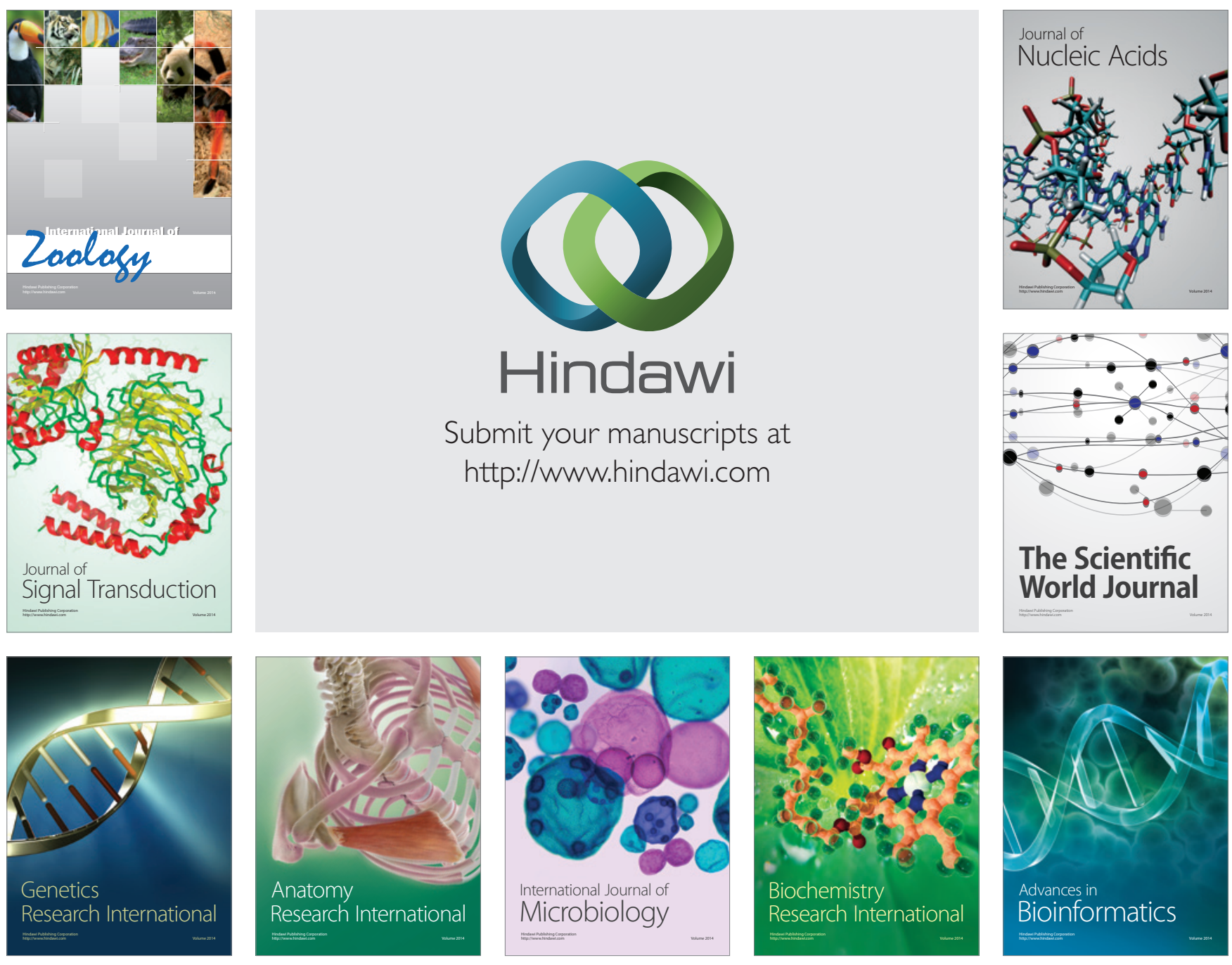

The Scientific World Journal
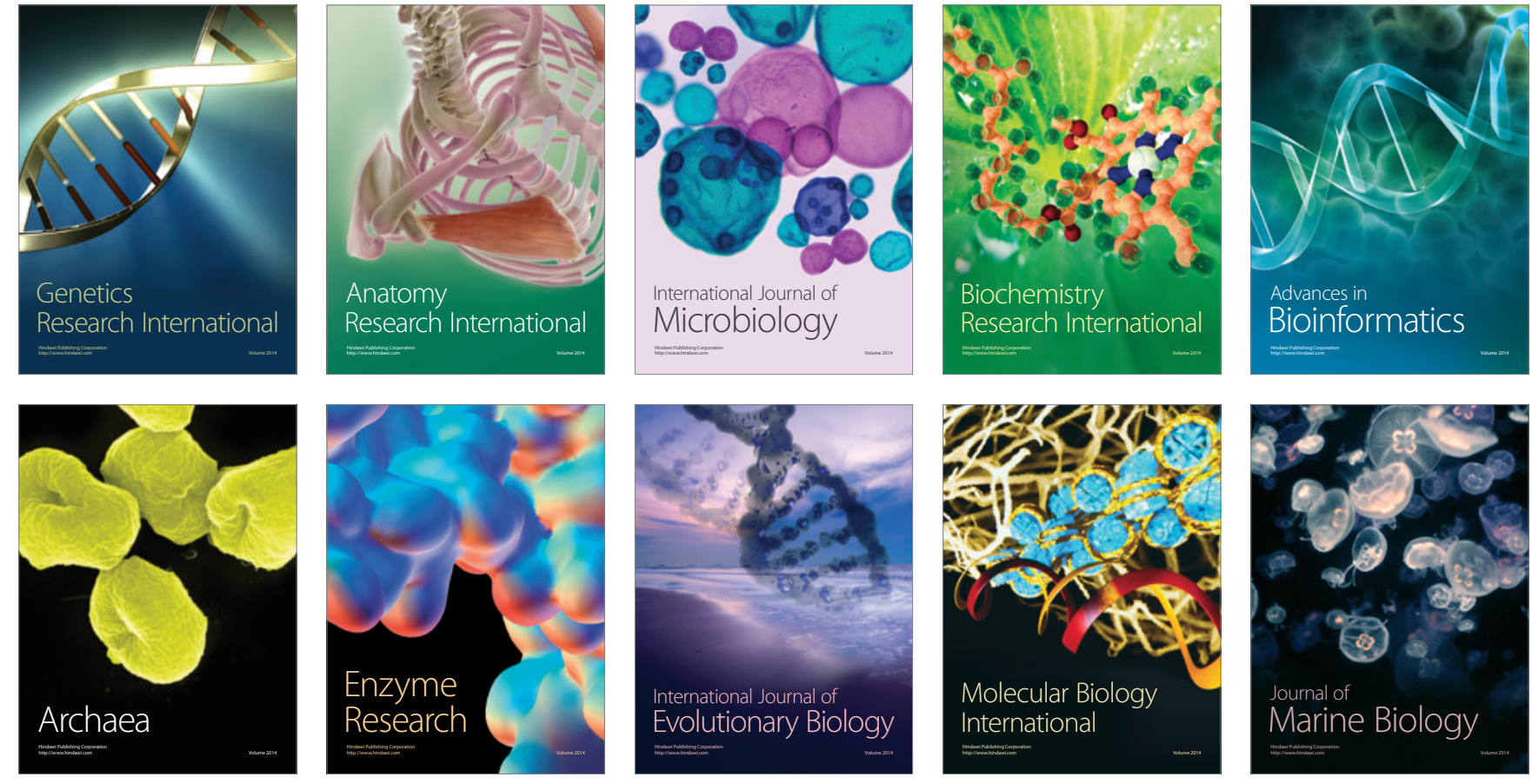